\title{
Feeding preference of Plutella xylostella for leaves treated with plant extracts
}

\author{
IRYS F.S. COUTO ${ }^{1}$, MATEUS L. FUCHS ${ }^{2}$, FABRÍCIO F. PEREIRA ${ }^{1}$, MUNIR MAUAD ${ }^{2}$, \\ SILVANA P.Q. SCALON ${ }^{2}$, DAIANE M. DRESCH ${ }^{2}$ and ROSILDA M. MUSSURY ${ }^{1}$ \\ ${ }^{1}$ Universidade Federal da Grande Dourados/ UFGD, Faculdade de Ciências Biológicas e Ambientais/ \\ FCBA, Rodovia Dourados - Itahum Km 12, 79804-970 Dourados, MS, Brasil \\ ${ }^{2}$ Universidade Federal da Grande Dourados/ UFGD, Faculdade de Ciências Agrárias/ FCA, \\ Rodovia Dourados - Itahum Km 12, 79804-970 Dourados, MS, Brasil
}

Manuscript received on March 30, 2015; accepted for publication on December 17, 2015

\begin{abstract}
Plutella xylostella L. is one of the main agents to cause damages to plants of Brassica genus, provoking negative impacts in cultures. The use of botanical extracts in plants protection has been related in literature, however, their use in the species analyzed in this study is not yet reported. We assessed the effect of aqueous and methanolic extracts of the species: Schinus terebinthifolius Raddi (Pink Pepper), Annona coriacea Mart. (Araticum), Duguetia furfuracea (A. St.-Hil.) Benth. \& Hook. (Pindaúva do campo) and Trichilia silvatica C. DC. (Catiguá-branco), occuring in the state of Mato Grosso do Sul and whose feeding preference of $P$. xylostella larvae of 3rd instar. We intend to answer the following questions: (1) Are the plant species analyzed fagodeterrentes? (2) what type of extract produces the least food preferrence? To answer these questions, we treated cabbage disks with aqueous extracts stored in a refrigerator in periods of $0,7,14$ and 21 days and the methanolic extracts were treated at concentrations of $0.5 \mathrm{mg} / \mathrm{mL}, 1.0 \mathrm{mg} /$ $\mathrm{mL}, 2.0 \mathrm{mg} / \mathrm{mL}$. The aqueous and methanolic extracts of $T$. silvatica presented the lowest values of feeding preference, 0.113 and 0.06 , respectively, compared to other extracts.
\end{abstract}

Key words: Annona coriacea, Duguetia furfuracea, Feeding deterrence, insecticidal plant, Schinus terebinthifolius, Trichilia silvatica.

\section{INTRODUCTION}

The wide-scale use of agrotoxic compounds and synthetic insecticides highlights the need to develop new technologies that will minimize their usage. Ecologically aware consumers and producers prefer organic crops that are free of agrotoxic compounds and drive research on products that do not harm the environment (Krinsk et al. 2014).

Correspondence to: Rosilda Mara Mussury

E-mail: maramussury@ufgd.edu.br
The control of pests through alternative control methods, specifically with plant extracts, is being increasingly studied in order to minimize the chemical impact of insecticides (Mazzonetto et al. 2013).

Plutella xylostella (Lepidoptera: Plutellidae), commonly known as a cabbage moth, is considered to be the main agent responsible for damage to brassicas in commercial plantations worldwide, due to its high feeding rate during the larval period that causes substantial damage to crops, up to $100 \%$ 
yield loss (Hamilton et al. 2005). Furthermore, the average annual cost of pest control exceeds one billion dollars (Talekar 1992, Yang et al. 1994, Haseeb et al. 2004).

For the control of Plutellaxylostella (Linnaeus, 1758) (Lepidoptera: Plutellidae) the unselective use of synthetic insecticides has been reported (Boiça Júnior et al. 2005), and has led to the emergence of resistant populations (Talekar and Shelton 1993, Furlong et al. 2013). Recent studies have focused on the control of insects using plants (Girão Filho et al. 2014, Trindade et al. 2011, Boiça Júnior et al. 2013). Previous studies have analyzed plant species and brassica cultivars that are resistant to insects (Sarfraz et al. 2010, Niu et al. 2014), and the contents of their aqueous and ethanolic extracts, which interfere with insect feeding and development (Trindade et al. 2008, Bandeira et al. 2013, Boiça Júnior et al. 2013).

Therefore, research on alternative control measures is underway and includes the use of plants, which are important for the sustainable control of insects. Plants tend to have a wide spectrum of activity (such as toxicity, repellence, feeding and oviposition inhibition, and insect growth regulation), and a relatively specific mode of action (Torres et al. 2006, Maia and Moore 2011, Conceschi et al. 2011, Liang et al. 2012, Niu et al. 2013, Amoabeng et al. 2014), ie therefore, each plant species has a specific mode of action on certain target insects according to the chemical compound they have, being innocuous to non-target organisms. Furthermore, their use is safe for larger animals as well as the environment, and the formulations that use plants as the primary material can be easily produced by farmers and small industries (Talukder and Howse 1994). According to Viglianco et al. (2006), most plant-based insecticides do not contribute to the development of resistance or to the emergence of pests. Furthermore, they do not have negative effects on non-target organisms or affect plant growth, seed viability, or the quality of products.
Taking into account the economic importance of brassicas and the negative impact caused by P. xylostella, we aimed to assess the following questions: (1) which of the analyzed species are phagodeterrents and (2) which plant extract is least preferred by the larvae for feeding?

Therefore, we focused on assessing the feeding preference of $P$. xylostella larvae for samples of cabbage leaves treated with aqueous and methanolic extracts of botanical species widely present in forests and Cerrado of Mato Grosso do Sul. The species include: Schinus terebinthifolius Raddi (pink pepper), Annona coriacea Mart. (araticum), Duguetia furfuracea (A. ST.-Hill.) Benth. \& Hook. (pindaúva-do-campo) and Trichilia silvatica C. DC (white catiguá). Until the present moment, such species have not been evaluated according to their role in P. xylostella feeding preference. We hope that, in the future, we be able to use the agricultural properties of these species as an alternative method of plague control and are widely spread in the state.

\section{MATERIALS AND METHODS}

Plutella xylostella were reared in a laboratory under $25 \pm 1{ }^{\circ} \mathrm{C}, 55 \pm 5 \% \mathrm{RH}$ with a photoperiod of 12 $\mathrm{h}$, using larvae and pupae collected from cabbage fields.

The adults were kept in a plastic cage and fed on a $10 \mathrm{mg} / \mathrm{mL}$ honey solution, provided on cotton. To obtain the eggs, a cabbage disc over a damp filter paper was placed inside the cage.

After oviposition, the leaves with eggs were placed in sterilized $30 \times 15 \times 12 \mathrm{~cm}$ plastic vessels to be used as pupation substrate. First, second, third, and fourth instar larvae were fed on organic cabbage leaves, initially sterilized using a solution of $5 \%$ sodium hypochlorite and then washed in running water before being placed into the recipients.

The healthy cabbage leaves were placed with the adaxial side towards the plastic recipient and the free abaxial side was used to place the larvae. Next, 
another cabbage leaf was placed with the abaxial side towards the larvae. The cabbage leaves were replaced daily or as soon as they wilted, ensuring that the larvae were always provided with the best leaves. This process was repeated daily until pupae were formed (Barros et al. 2012).

Healthy, completely expanded leaves of Annona coriacea, Duguetia furfuracea, Schinus terebinthifolius, and Trichilia silvatica, were collected from the medicinal plant garden at the Federal University of Grande Dourados - UFGD and from properties in Coqueiro (outback) and Santa Madalena (Cerrado) in the municipality of Dourados - MS (22 $14^{\prime}$ S, 54 $9^{\circ} \mathrm{W}$ longitude and $452 \mathrm{~m}$ altitude).

The species were identified by comparison with exsiccates in the herbarium at UFGD (DDMS). The plant material was kept in the herbarium at the Faculty of Biological and Environmental Sciences at UFGD with the number Annona coriacea: DDMS 4891, Duguetia furfuracea: DDMS 4890, Schinus terebinthifolius: DDMS 4889, and Trichilia silvatica: DDMS 4662.

The leaves were dried in a forced air circulation incubator for three days at a maximum temperature of $40^{\circ} \mathrm{C}\left( \pm 1^{\circ} \mathrm{C}\right)$. After this period, the dried leaves were ground to obtain a fine, dry powder.

The aqueous and methanolic extracts were prepared by maceration. The aqueous extracts (AE) were prepared, separately, from 10-g of plant material with $100-\mathrm{mL}$ of distilled water. Next, the material was filtered through a filter paper to remove the solid material. The extracts were stored at $-4^{\circ} \mathrm{C}$ and then tested on days $0,7,14$, and 21 .

To prepare the methanolic extract (ME), a 100$\mathrm{g}$ sample of the powder was placed into a beaker with 1000-L of solvent (methanol) and macerated for 7 days. Filtering was performed every two days, for 30 days. The filtered extract was concentrated using a rotavapor set at $60^{\circ} \mathrm{C}$, at a reduced pressure. The product obtained in this process was dissolved in distilled water at concentrations of $0.5 \mathrm{mg} / \mathrm{mL}$,
$1.0 \mathrm{mg} / \mathrm{mL}$, and $2.0 \mathrm{mg} / \mathrm{mL}$ for subsequent use in the tests.

The free-choice tests were performed at $25 \pm$ $1{ }^{\circ} \mathrm{C}, 55 \pm 5 \% \mathrm{RH}$, and a photoperiod of $12 \mathrm{~h}$. The cabbage fragments $\left(4 \mathrm{~cm}^{2}\right)$ were placed in a Petri dish and distributed in the form of a cross, equidistant to one another, with two fragments immersed in the extract and two immersed in distilled water. Five third instar larvae of P. xylostella were placed on each dish, where larval instar was identified by the length of the larval cephalic capsule (0.33-0.44 mm).

After $24 \mathrm{~h}$, the insect was removed, the leaf area was scanned, and the measurements were made from the images using the software Image J (Shneider et al. 2012). Leaf consumption was determined as the difference between the initial leaf area and the remaining leaf area after larval feeding.

The experiment was carried out in a completely randomized factorial design for the aqueous extract (four plants $\times$ four periods) and the methanolic extract (four plants $\times 3$ concentrations), both with five repetitions, and each containing 10 subsamples. Analyses of variance were performed on the data; for the aqueous extract, regression analysis at 5\% probability was carried out, using the software SISVAR 4.2. For the methanolic extract, the means were compared using Tukey's test at $5 \%$ probability using the software SANEST (Zonta 1984).

The response of the larvae to the plant extract was assessed using the feeding preference index (PI) (Kogan and Goeden 1970), being classified as phagostimulant with an index greater than 1 , neutral if equal to 1 , and phagodeterrent if less than 1, using the formula: $\mathrm{PI}=2 \mathrm{~A} /(\mathrm{M}+\mathrm{A})$, where: $\mathrm{A}$ = area consumed from the treated discs; $\mathrm{M}=$ area consumed of untreated discs.

\section{RESULTS}

There was variation in the preference index of $P$. xylostella during the storage period of the tested aqueous extracts (Figure 1). 
The aqueous extract of $A$. coriacea after days 0 and 7 showed a phagostimulant effect, with the PI gradually decreasing after 7 days changing from a phagostimulant to a phagodeterrent.

For S. terebinthifolius, there was a gradual decrease in the PI during the experimental period, with the aqueous extract acting as a phagostimulant with a PI greater than $1(1.16)$ at period 0 , and this number reduced by half (0.56) after 21 days.

The aqueous extracts of $D$. furfuracea and $T$. silvatica acted as phagodeterrents during the whole storage period, with the minimum storage period of $D$. furfuracea being 15 days $(\mathrm{y}=15.18)$, and 11 days for $T$. silvatica $(\mathrm{y}=11.19)$. The aqueous extract of $T$. silvatica after 21 days had greater PI values when compared to days 7 and 14 .

A lower preference index $(\mathrm{PI}=0.113)$ was achieved for all tested aqueous extracts from $T$. silvatica after 11 days of rearing.

For the methanolic extract, PI was significantly affected by the concentration of the extract $(0.7714514 ; P \leq 0.05)$, the plant species $(0.7034860$; $P \leq 0.05)$, and the interaction between the extract concentration and plant species (Table I).

There were no significant differences between the feeding preference indices at concentrations of $0.5 \mathrm{mg} / \mathrm{mL}$ and $1.0 \mathrm{mg} / \mathrm{mL}$ for the methanolic extracts of $A$. coriacea, $S$. terebinthifolius, and $D$. furfuracea.

At a concentration of $2.0 \mathrm{mg} / \mathrm{mL}$, there was no variation between $A$. coriacea and $S$. terebinthifolius; however, D. furfuracea had a lower PI than the other species used in this study.

The methanolic extract from $T$. silvatica showed the best results at all concentrations, and therefore, led to the lowest leaf consumption by $P$. xylostella.

The aqueous and methanolic extracts of $T$. silvatica had the lowest PIs, at 0.113 (Figure 1) and 0.06 (Table I), respectively.

With regard to the types of extract, the leaf samples treated with water were preferred by the insects and the methanolic treatment for all treatments was least preferred by the insects. The methanolic extract of $T$. silvatica resulted in less leaf area being consumed by $P$. xylostella .

\section{DISCUSSION}

The results obtained from the feeding preference tests performed in this study revealed that the aqueous and methanolic extracts of $T$. silvatica were the most effective antifeedants on third instar $P$. xylostella larvae. Decreased feeding in insects has been reported in response to different Trichilia plant extracts (Ramírez et al. 2000, Wheeler et al. 2001, Rodriguez et al. 2003). Many species of Trichilia have effects on insects, including inhibition and regulation of growth (Koul et al. 2004), cytotoxic activity (Roel et al. 2000, Souza and Vendramim 2001, Cunha et al. 2008), and insecticidal activity (Matos et al. 2009, Nebo et al. 2010).

Limonoids, also known as meliacines, are the most abundant metabolites in Meliaceae (Viegas Junior 2003). The phagodeterrence of limonoids appears to occur due to the effect of their mouthparts (dissuasion), and also due to their post-ingestion toxicity (Mordue and Blackwell 1993).

Species of the genus Trichilia, studied by Medeiros et al. (2005), demonstrated a deterrent action towards oviposition, with $T$. pallida being $100 \%$ deterrent for oviposition of cabbage moths. Thus, it is possible that species belonging to the genus Trichilia produce the same class of secondary metabolites, and therefore, the deterrence of oviposition in $T$. silvatica should be assessed.

In this study, treatments using aqueous extracts of the four plant species showed that the production and immediate application of the extracts did not cause obvious antifeeding, with the PI varying between 0.9 and 1.1. The results demonstrated the efficient antifeeding effect of extracts on $P$. xylostella larvae for the time during which each aqueous extract was stored, with each species having a more efficient storage period, i.e., time during which their PI is the lowest. 


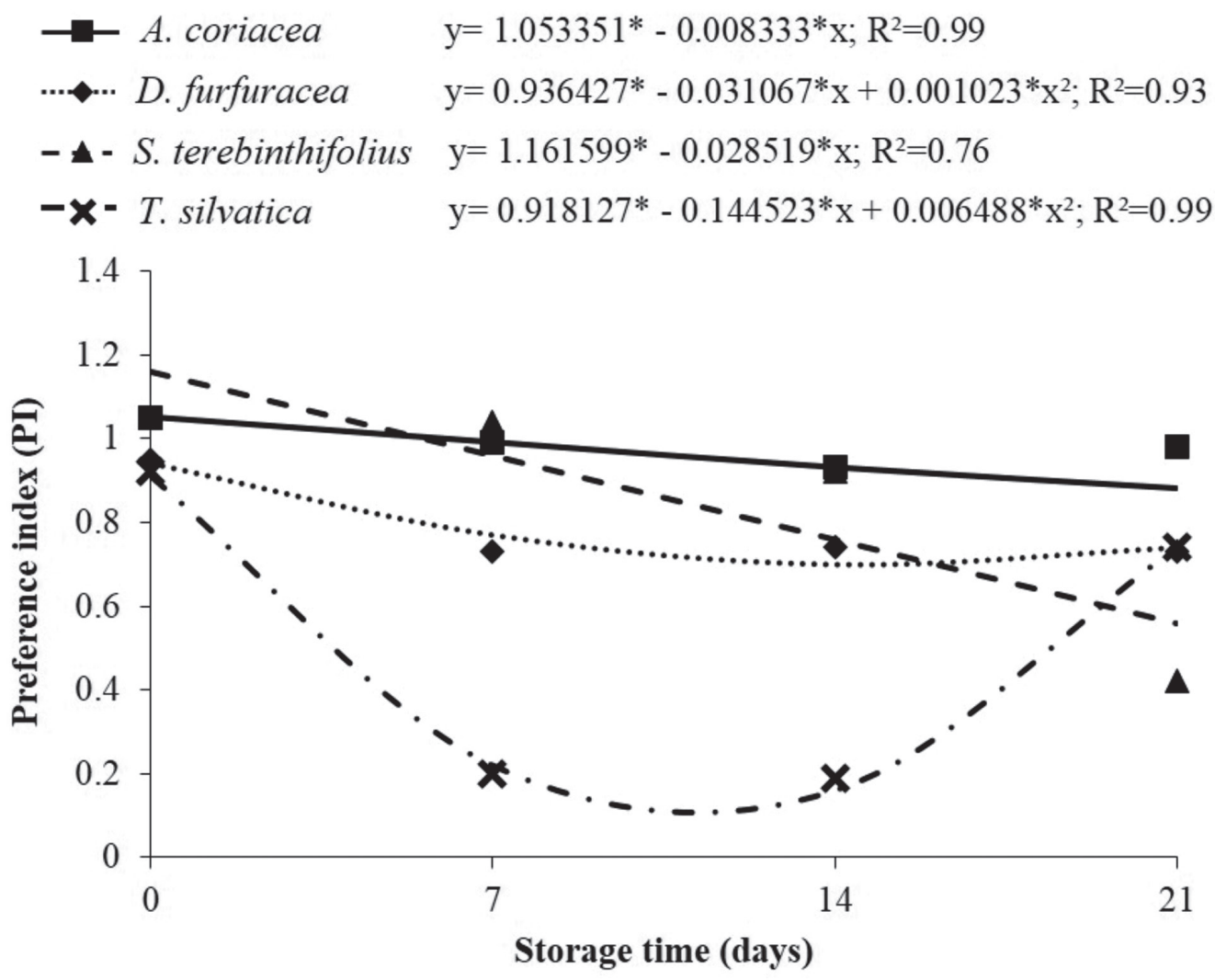

Figure 1 - Preference index (PI) of Plutella xylostella with regard to plant extract and storage period of each extract at a temperature of $25 \pm 1{ }^{\circ} \mathrm{C}$, relative humidity of $55 \pm 5 \%$ with a photoperiod of $12 \mathrm{~h}$. Dourados-MS. (*significance level at $5 \%$ probability).

TABLE I

Preference index (PI) and area consumed by Plutella xylostella per cabbage under different concentrations of $(\mathrm{mg} / \mathrm{mL})$ methanolic extracts.

\begin{tabular}{cccccccccc}
\hline & \multicolumn{7}{c}{ Concentrations } \\
\cline { 2 - 9 } Plant & 0.5 & 1.0 & 2.0 & 0.5 & 1.0 & 2.0 & 0.5 & 1.0 \\
\cline { 2 - 9 } & & PI & & Area consumed with extract $\left(\mathrm{cm}^{2}\right)$ & Area consumed with water $\left(\mathrm{cm}^{2}\right)$ \\
\hline A. coriaceae & $0.81 \mathrm{bC}$ & $0.63 \mathrm{bB}$ & $0.51 \mathrm{cA}$ & 0.99 & 0.45 & 0.85 & 1.5 & 0.98 & 2.53 \\
D. furfuracea & $0.88 \mathrm{bC}$ & $0.73 \mathrm{bB}$ & $0.37 \mathrm{bA}$ & 1.2 & 0.88 & 0.32 & 1.51 & 1.56 & 1.45 \\
S. terebinthifolius & $0.88 \mathrm{bB}$ & $0.73 \mathrm{bA}$ & $0.61 \mathrm{cA}$ & 0.65 & 0.91 & 0.53 & 0.82 & 1.62 & 1.23 \\
T. silvatica & $0.53 \mathrm{aC}$ & $0.19 \mathrm{aB}$ & $0.06 \mathrm{aA}$ & 0.95 & 0.34 & 0.13 & 2.69 & 3.51 & 3.89 \\
\hline
\end{tabular}

F (Concentrations x Plant) $0.0311162 *$

Means followed by the same lowercase letters per column and uppercase per line, are significantly different as per the results of the Tukey's test at 5\% probability.

All methanolic extracts tested conferred antifeeding effects, and were most efficient at the highest concentration tested.

The larvicidal potential of $D$. furfuracea has been reported by Rodrigues et al. (2006) and Silva et al. (2013) for other insects. For P. xylostella and $D$. furfuracea, the avoidance of feeding on discs treated with aqueous and methanolic extracts, may have occurred due to phagodeterrence, probably caused by the presence of secondary metabolites 
(flavonoids, alkaloids, acetogenins in annonas, and terpenes) (Isman 2006). Duguetine, which belongs to the class of aporfinic alkaloids, is present in the genus Duguetia, which according to Silva et al. $(2007,2009)$ has insecticidal properties.

In a recent study, Krinski et al. (2014) showed the efficiency of annonas as insecticidal plants to different insects. However, for A. coriacea, there have been no reports in the literature for the control of P. xylostella. Acetogenin, a substance present in annonas, acts on insects by targeting the mitochondria and inhibiting $\mathrm{NADH}$, leading to death of these insects (Zafra-Polo et al. 1996).

The bioactivity of acetogenins may vary significantly depending on the species, as well as solvent used in the extraction (Chirinos et al. 2007, Shaalan et al. 2005). With regard to the order Lepidoptera, a recent study by Freitas et al. (2014) showed the control of $S$. frugiperda using plant extracts by reducing the viability of the larval phase. Extracts of A. coriacea added to the diet of Anagasta kuehniella caused death in $50 \%$ of the larvae, and acted as an antifeedant (Coelho et al. 2007).

It is important to note that the aqueous extracts (7 to 21 days of storage) and methanolic extracts of $S$. terebinthifolius have a phagodeterrent effect on P. xylostella, which is supported by the presence of secondary metabolites, including tannins and flavonoids (isolated form leaves of $S$. terebinthifolius) (A. Salvi Júnior, unpublished data, Johann et al. 2010). Tannins inhibit digestion by inactivating digestive enzymes creating a tanninprotein complex that is difficult to digest, thereby affecting insect growth and survival (Mello and Silva-Filho 2002).

It was observed that the feeding deterrence of $P$. xylostella larvae was greater in response to methanolic extracts when compared to aqueous extracts. This may have occurred due to the solvents used during the extraction of secondary metabolites, with methanol extracting a larger number of secondary compounds. R.J.P. Moura
(Unpublished data) extracted flavonoids and phenols using different solvents, including water, ethanol, and methanol. Methanol was more efficient for extracting these compounds than water, as it had a higher extractive capacity (Barros et al. 2011).

The using aqueous and methanolic extracts of plant species is an excellent alternative to prevent damage to crops caused by P. xylostella. The storage period of the extract, the solvent used during extraction, and the different concentrations used are factors that influence the feeding preference of P. xylostella.

The results of our study will facilitate future research on the identification of potential bioinsecticidal plant species as well as their chemical characterization, including identification of the compounds or class of compounds responsible for insecticidal activity.

It is concluded that all the species tested are phagodeterrents and the methanolic extract from $T$. silvatica shows the lowest leaf consumption by larvae of P. xylostella.

\section{ACKNOWLEDGMENTS}

We would like to thank the Federal University of Grande Dourados (UFGD) and Fundação de Apoio ao Desenvolvimento do Ensino, Ciência e Tecnologia do Estado de Mato Grosso do Sul (FUNDECT), for the financial aid and Coordenação de Aperfeiçoamento de Pessoal de Nível Superior (CAPES) for the Master's scholarship awarded to the primary author. We also thanks the Laboratory of Insect-Plant Interactions (LIIP) and the Laboratory of Entomology and Biological Control (LECOBIOL) at the Faculty of Biological and Environmental Sciences (FCBA) for logistical support.

\section{RESUMO}

Plutella xylostella L. é um dos principais agentes de danos as brássicas causando impactos negativos às 
culturas. A utilização de extratos botânicos é relatada na literatura para proteção de plantas, no entanto, para as espécies analisadas no presente trabalho ainda não foi relatado. Examinamos o efeito de extratos aquosos e metanólicos de quatro espécies de plantas: Schinus terebinthifolius Raddi (pimenta-rosa), Annona coriacea Mart. (araticum), Duguetia furfuracea (A. ST.-Hil.) Benth. \& Hook. (pindaúva-do-campo) e Trichilia silvatica C. DC. (catiguá-branco) de ocorrência no estado de Mato Grosso do Sul, e que, até o momento não foram avaliadas quanto à preferência alimentar por larvas de $3^{\circ}$ ínstar de P. xylostella. Pretendemos responder as seguintes questões: (1) as espécies vegetais analisadas são fagodeterrentes? (2) qual o tipo de extrato que produz a menor preferência alimentar? Para responder a essas questões discos de couve foram tratados com extratos aquosos armazenados em refrigerador nos períodos de $0,7,14$ e 21 dias e os extratos metanólicos nas concentrações de $0,5 \mathrm{mg} / \mathrm{mL}, 1,0 \mathrm{mg} / \mathrm{mL}, 2,0 \mathrm{mg} /$ $\mathrm{mL}$. Os extratos aquoso e metanólico de $T$. silvatica apresentaram os menores valores de preferência alimentar 0,113 e 0,06, respectivamente, em relação aos outros extratos.

Palavras-chave: Annona coriacea, Duguetia furfuracea, deterrencia alimentar, planta inseticida, Schinus terebinthifolius, Trichilia silvatica.

\section{REFERENCES}

AMOABEnG BW, GuRRB GM, GitAu CW AND STEVEnSON PC. 2014. Cost: benefit analysis of botanical insecticide use in cabbage: Implications for smallholder farmers in developing countries. Crop Protection 57: 71-76.

BANDEIRA GN, CAMARA CAG, MORAES MM, BARRoS R, MUHAMMAD S AND AKHTAR Y. 2013. Insecticidal activity of Muntingia calabura extracts against larvae and pupae of diamondback, Plutella xylostella (Lepidoptera, Plutellidae). J King Saud Univ Sci 25: 83-89.

BARRos L, CARVALHO A AND FERREIRA I. 2011. Comparing the composition and bioactivity of Crataegus Monogyna flowers and fruits used in folk medicine. Phytochem Anal 22: 181-188.

BArros R, THuler RT AND PEREIRA FF. 2012. Técnica de criação de Plutella xylostella (L., 1758) (Lepidoptera: Yponomeutidae). In: Pratissoli D (Org), Técnicas de criação de pragas de importância agrícola, em dietas naturais. $1^{\mathrm{a}}$ ed., Vitória: EDUFES, p. 65-83.

BOIÇA JÚNIOR AL, JANINI JC, DE SOUZA BHS AND RODRIGUES NEL. 2013. Effect of cabbage cultivars and doses of aqueous extrat of neem on feeding and biology of Plutella xylostella Linnaeus) (Lepidoptera: Plutellidae). Biosci J 29: 22-31.

BOIÇA JÚNIOR AL, MEDEIROS CAM, TORRES AL AND CHAGAS NRF. 2005. Efeito de extratos aquosos de plantas do desenvolvimento de Plutella xylostella (L.) (Lepidoptera: Plutellidae) em couve. Arq Inst Biol 72: 4550.

Chirinos R, Rogez H, CAMpos D, PEdreschi R AND LARONDELLE Y. 2007. Optimization of extraction conditions of antioxidant phenolic compounds from mashua (Tropaeolum tuberosum Ruíz \& Pavón) tubers. Sep Purif Technol 55: 217-225.

Coelho MB, Marangoni S And MaCedo ML. 2007. Insecticidal action of Annona coriacea lectin against the flour moth Anagasta kuehniella and the rice moth Corcyra cephalonica Lepidoptera: Pyralidae). Comp Biochem Physiol C Toxicol Pharmacol 146: 406-414.

CONCESCHi MR, Ansante TF, Mazzonetto F, Vendramim JD, Sossai VLM, PizetTa LC AND CORBANI RZ. 2011. Effects of aqueous extract from Azadirachta indica and Trichilia pallida on Spodoptera frugiperda (J. E. Smith) (Lepidoptera: Noctuidae) in maze. BioAssay 6: 1-6.

CUNHA US, VENDRAMIM JD, ROCHA WC AND VIEIRA PC. 2008. Bioactivity of Trichilia pallida Swartz (Meliaceae) derived molecules on Tuta absoluta (Meyrick) (Lepidoptera: Gelechiidae). Neotrop Entomol 37: 709-715.

FreitAS AF, PEREIRA FF, FORMAGIO ASN, LUCCHETTA JT, VieIRA MC AND Mussury RM. 2014. Effects of Methanolic Extracts of Annona Species on the Development and Reproduction of Spodoptera frugiperda (J.E. Smith) (Lepidoptera: Noctuidae). Neotrop Entomol 43: 446-452.

FURLONG MJ, WRIGHT DJ AND DOSDALL LM. 2013. Diamondback Moth Ecology and Management: Problems, Progress, and Prospects. Annu Rev Entomol 58: 517-541.

Girão FilHo JE, ALCANTARA NETO F, PÁdUA LEM AND PESSOA EF. 2014. Repellency and insecticidal activity of plant powders on Zabrotes subfasciatus (Boh.) on stored lima beans. Rev Bras Plantas Med 16: 499-504.

HAMILTON AJ, ENDERSBY NM, RIDLAND PM, ZHANG J AND NEAL M. 2005. Effects of cultivar on oviposition preference, larval feeding and development time of diamondback moth, Plutella xylostella (L.) (Lepidoptera: Plutellidae), on some Brassica oleracea vegetables in Victoria. Aust J Entomol 44: 284-287.

HASEEB M, LIU TX AND JONES WA. 2004. Effects of selected insecticides on Cotesia plutellae, endoparasitoid of Plutella xylostella. Bio Control 49: 33-46.

ISMAN MB. 2006. Botanical insecticides, deterrents, and repellents in modern agriculture and an increasingly regulated world. Annu Rev Entomol 51: 45-46. 
JOHANN S, SÁ NP, LIMA LARS, CISALPINO PS, COTA BB, Alves TM, SIQUeIRA EP AND ZANi CL. 2010. Antifungal activity of schinol and a new biphenyl compound isolated from Schinus terebinthifolius against the pathogenic fungus Paracoccidioides brasiliensis. Ann Clin Microbiol Antimicrob 12: 9-30.

KogAN M AND GoEDEN RD. 1970. The host-plant range of Lema trilineata daturaphila (Coleoptera: Chrysomelidae). Ann Entomol Soc Am 63: 1175-1180.

Koul O, Singh G, Singh R, DANiewski WM AND BERLOZECKI S. 2004. Bioefficacy and mode-of-action of some limonoids of salannin group from Azadirachta indica A. Juss and their role in a multicomponent system against lepidopteron larvae. J Biosci 29: 409-416.

Krinski D, MASSAROLI A AND MACHAdo M. 2014. Insecticidal potential of the Annonaceae family plants. Rev Bras Frut 36: 225-242.

LIANG P, TIAN YA, BIONDI A, DESNEUX N AND GAO XW. 2012. Short-term and transgenerational effects of the neonicotinoid nitenpyram on susceptibility to insecticides in two whitefly species. Ecotoxicology 21: 1889-1898.

MAIA MF AND MOORE SJ. 2011. Plant-based insect repellents: a review of their efficacy, development and testing. Malaria J 10(Suppl 1): S11: 6-14.

Matos AP, Nebo L, Vieira PC, FERnANDEs JB, DA Silva MFGF AND RodRigues RR. 2009. Chemical constituents and insecticidal activity from fruits extracts of Trichilia elegans and T. catigua (Meliaceae). Quim Nova 32: 1553-1556.

MazzonetTo F, CORBAni RZ AND DALRi AB. 2013. Biofumigation of plant species on Sitophilus zeamais in stored maize. Appl Res Agrotecnol 6: 53-61.

Mello MO AND SILVA-FILHO MC. 2002. Plant-insect interactions: an evolutionary arms race between two distinct defense mechanisms. Braz J Plant Physiol 14: 71-81.

MEdeIros CAM, BoIÇA JÚNIOR AL AND TORRES AL. 2005. Effect of plants aqueous extracts on oviposition of the diamondback, in kale. Bragantia 64: 227-232.

MorduE AJ AND BLACKWELL A. 1993. Azadirachtin: an update. J Insect Physiol 39: 903-924.

Nebo L, Matos AP, Vieira PC, Fernandes JB, Silva MFGF AND RODRIGUES RR. 2010. Insecticidal activity of Trichilia claussenii (Meliaceae) fruits against Spodoptera frugiperda. Quim Nova 33: 1849-1852.

NIU YQ, LI XW, LI P AND LIU TX. 2013. Effects of different cruciferous crops on the fitness of Plutella xylostella (Lepidoptera, Plutellidae). Crop Protection 54: 100-105.

NIU YQ, LI XW, LI P AND LIU TX. 2014. Development and Reproductive Potential of Diamondback Moth (Lepidoptera: Plutellidae) on Selected Wild Crucifer Species. Environ Entomol 43: 69-74.

RAMÍREZ MC, TOSCANO RA, ARNASON J, OMAR S, ROJAS CMCG AND MATA R. 2000. Structure, conformation and absolute configuration of new antifeedant dolabellanes from Trichilia trifolia. Tetrahedron 56: 5085-5091.

Rodrigues AMS, DE PAula JE, Degallier N, Molez JF AND ESPÍNDOLA LS. 2006. Larvicidal activity of some cerrado plant extracts against Aedes aegypti. J Am Mosq Contr Assoc 22: 314-317.

Rodriguez B, CABallero C, ORtego F And CASTAÑERA P. 2003. A new tetranortriterpenoid from Trichilia havanensis. J Nat Prod 66: 452-454.

ROEL AR, VENDRAMIM JD, FRIGHETTO RTS AND FRIGHETTO N. 2000. Effect of ethyl acetate extract of Trichilia pallida Swartz (Meliaceae) on development and survival of fall armyworm. Bragantia 59: 53-58.

SARFRAZ RM, DOSALl LM AND KeddiE BA. 2010. Performance of the specialist herbivore Plutella xylostella (Ledipotera: Plutellidae) on Brassicaceae and nonBrassicacea especies. Can Entomol 142: 24-35.

SCHNEIDER CA, RASBAND WS AND ELICEIRI KW. 2012. NIH Image to ImageJ: 25 years of image analysis. Nature Methods 9: 671-675.

SHAALAN EAS, CANYON D, YOUNES MWF, ABDELWAHAB H AND MANSOUR AH. 2005. A review of botanical phytochemicals with mosquitocidal potential. Environ Int 31: 1149-1166.

Silva DB, Tulli ECO, Garcez WS, NAscimento EA AND SiqueIRA JM. 2007. Chemical Constituents of the Underground Stem Bark of Duguetia furfuracea (Annonaceae). J Braz Chem Soc 18: 1560-1565.

Silva DB, Tulli ECO, Militão GC, Costa-Lotufo LV, Pessoa C, De Moraes Mo, Albuquerque S AND DE SIQUEIRA JM. 2009. The antitumoral, trypanocidal and antileishmanial activities of extract and alkaloids isolated from Duguetia furfuracea. Phytomedicine 16: 1059-1063.

Silva JF, MELO BA, CORDEIRO MFR, LEITE DT AND BULHÕES AA. 2013. Response of Sitophilus zeamais Motschulsky 1885 (Coleoptera: Curculionidae) against the extract of Capsicum annuum L. Rev Verde 8: 05-08.

SOUZA AP AND VENDRAMIM JD. 2001. Insecticidal Activity of Aqueous Extracts of Meliaceae Plants on the Silverleaf Whitefly, Bemisia tabaci (Genn.) Biotype B (Hemiptera: Aleyrodidae). Neotrop Entomol 30: 133-137.

TALEKAR NS. 1992. Management of diamondback moth and other crucifer pests. Proc. 2nd Int Workshop, AVRDC, Shanhua, Taiwan, $603 \mathrm{p}$.

TAleKar N AND Shelton A. 1993. Biology, ecology, and management of the diamondback moth. Ann Rev Entomol 38: 275-301.

TALUKDER FA AND HowsE PE. 1994. Laboratory evaluation of toxic repellent properties of the pithraj tree, Aphanamixis polystachya Wall \& Parker, against Sitophilus oryzae (L.). Int J Pest Manage 40: 274-279.

TORRES AL, BOIÇA JÚNIOR AL, MEDEIROS CAM AND BARROS R. 2006. Effect of aqueous extracts of 
Azadirachta indica (A. Juss), Melia azedarach (L.) and Aspidosperma pyrifolium (Mart.) on the development and oviposition of Plutella xylostella (L.) (Lepidoptera: Plutellidae). Bragantia 65: 447-457.

TRINDADE RCP, DA Silva PP, ARAÚJO-JÚNIOR JX, DE LIMA IS, DE PAUlA JE AND SANT'ANA AEG. 2008. Mortality of Plutella xylostella larvae treated with Aspidosperma pyrifolium ethanol extracts. Pesq Agropec Bras 43: 1813-1816.

TRINDADE RCP, LUNA JS, LIMA MRF, Silva PP AND SANT'ANA AEG. 2011. Larvicidal activity and seasonal variation of Annona muricata (Annonaceae) extract on Plutella xylostella (Lepidoptera: Plutellidae). Rev Colomb Entomol 37: 223-227.

VIEGAS JUNIOR C. 2003. Terpenes with insecticidal activity: an alternative to chemical control of insects. Quím Nova 26: 390-400.

VIGLIANCO AI, NOVO RJ, CRAGNOLINI CI AND NASSETTA M. 2006. Actividad biológica de extractos crudos de
Larrea divaricata Cav. y Capparis atamisquea Kuntze sobre Sitophilus oryzae (L.). Agriscientia 23: 83-89.

WHEELER DA, ISMAN MB, SANCHEZ-VINDAS PE AND ARNASON JT. 2001. Screeneing of Costa Rican Trichilia species for biological activity against the larvae of Spodoptera litura (Lepidoptera: Noctuidae). Biochem Syst Ecol 29: 347-358.

YANG JC, CHU Y AND TALEKAR NS. 1994. Studies on the characteristics of parasitism Plutella xylostella (Lep.: Plutellidae) by a larval parasite Diadegma semiclausum (Hym.: chneumonidae). Entomophaga 39: 397-406.

ZAFrA-POLO MC, GONZÁlES MC, ESTORNELl E, SAHPAZ S AND CORTES D. 1996. Acetogenins from annonaceae, inhibitors of mitocondrial complex I. Phytochemistry 42: 253-271.

ZONTA EP, MACHADO AD AND SILVEIRA JUNIOR P. 1984. Sistema de análise estatística para microcomputadores: SANEST. Pelotas: UFPEL, (Registro SEI n ${ }^{\text {o. }}$ 06606-0 categoria AO). 